\title{
Estimasi Kelajuan dan Volume Kendaraan Berdasarkan Model Makroskopik Arus Lalu Lintas Jalan Tol dengan Metode Extended Kalman Filter
}

\author{
Febriana Prihatiningsih ${ }^{1}$, Sigit Pancahayani', dan Subchan ${ }^{3}$ \\ ${ }^{1}$ Program Studi Matematika, Institut Teknologi Kalimantan, Balikpapan. Email: febriana09021995@gmail.com \\ ${ }^{2}$ Program Studi Matematika, Institut Teknologi Kalimantan, Balikpapan. Email: spancahayani@itk.ac.id \\ ${ }^{3}$ Program Studi Matematika, Institut Teknologi Kalimantan, Balikpapan. Email: subchan@itk.ac.id
}

\begin{abstract}
In this thesis, the analysis of vehicles' determination of speed and volume in the traffic flow will be discussed by approach time. The analyzation of vehicles' speed and volume done by estimated on macroscopic term of traffic flow in the traffic jam with Extended Kalman Filter (EKF) method. The term of macroscopic views with measured the traffic variable by density the flow rate the flow rate of vehicle and also the vehicle speed's average. In the estimating process, forward difference scheme is implemented to the model and error are measured by Root Mean Square Error. The result showed that the estimation the average of the vehicle's relative speed in a segment decreased when its volume of vehicle is increased and vice versa.
\end{abstract}

Keywords: vehicle volume, velocity estimation, macroscopic models

\begin{abstract}
Abstrak
Pada penelitian ini dibahas mengenai analisis penentuan kelajuan dan volume kendaraan pada arus lalu lintas dengan pendiskritan waktu. Analisis kelajuan dan volume kendaraan dilakukan dengan estimasi pada model makroskopik arus lalu lintas jalan tol menggunakan metode Extended Kalman Filter (EKF). Model makroskopik dilihat dengan mengukur variabel lalu lintas melalui kepadatan laju aliran, tingkat arus kendaraan, dan rata-rata kecepatan kendaraan. Dalam prosesnya, diterapkan pendiskritan waktu menggunakan beda maju dan mengukur nilai kesalahan dengan Root Mean Square Error. Hasil yang di peroleh menunjukkan bahwa estimasi rata-rata kelajuan relatif kendaraan pada segmen terjadi peningkatan ketika volume kendaraan pada segmen berkurang dan begitu juga sebaliknya.
\end{abstract}

Kata Kunci: Volume kendaraan, estimasi kelajuan, model makroskopik

\section{Pendahuluan}

Kemacetan lalu lintas muncul ketika jumlah kendaraan lalu lintas melebihi kapasitas jalan atau persimpangan. Penambahan jumlah kendaraan dapat menyebabkan tundaan atau kemacetan, sehingga waktu perjalanan menjadi lebih lama dan mengakibatkan kenaikan biaya transportasi. Kondisi ini dapat digunakan sebagai dasar argumentasi untuk mengurangi terjadinya kemacetan pada suatu jalur lalu lintas.

Kemacetan merupakan kepadatan kendaraan di jalan raya yang disebabkan oleh kapasitas jalan yang tidak sepadan dengan jumlah kendaraan yang ada. Kemacetan lalu lintas di jalan juga terjadi karena ruas jalan yang sudah mulai tidak mampu menerima atau melewatkan arus kendaraan yang datang. Masalah arus lalu lintas di jalan raya dapat dipengaruhi oleh kelajuan arus lalu lintas, kepadatan arus lalu lintas, posisi kendaraan dan waktu yang dinyatakan sebagai variabel yang ada di jalan raya. 
Beberapa variabel yang mempengaruhi arus lalu lintas dimodelkan dengan dua pendekatan model arus lalu lintas yaitu model mikroskopik dan model makroskopik. Karakteristik arus lalu lintas berbeda-beda sesuai dengan kondisi jalur lalu lintas. Karakteristik ini menyebabkan kemacetan yang berbeda dalam setiap segmen, sehingga untuk memodelkan persamaan matematika dengan karakteristik yang berbeda digunakan suatu persamaan sistem hybrid.

Pada penelitian ini akan ditinjau permasalahan arus lalu lintas jalan tol dengan model makroskopik tak linear. Hal tersebut digunakan untuk mempelajari keterkaitan sifat permasalahan yang sedang diselidiki dengan data yang diperoleh untuk menganalisis dan memprediksi keadaan lalu lintas. Untuk menanggapi permasalahan tersebut, maka dilakukan suatu estimasi menggunakan metode Extended Kalman Filter.

\section{Metode}

\subsection{Karakteristik Model Arus Lalu Lintas}

Karakteristik arus lalu lintas merupakan hasil interaksi yang kompleks dari empat elemen utama sistem lalu lintas, yaitu pengemudi, kendaraan, jalan dan lingkungan. Karakteristik ini diperlukan sebagai acuan dalam perencanaan lalu lintas.

Model arus lalu lintas dibedakan menjadi dua yaitu model makroskopik dan mikroskopik. Model makroskopik adalah model yang mencirikan arus lalu lintas sebagai suatu kesatuan (sistem), sehingga diperoleh gambaran operasional sistem secara keseluruhan yang dapat dilihat dengan mengukur variabel lalu lintas dan karakteristik pola aliran lalu lintas dalam ruang dan waktu. Kemudian variabel dan karakteristik model mikroskopik lalu lintas mencirikan perilaku setiap kendaraan dalam arus lalu lintas yang saling mempengaruhi.

Karakteristik arus lalu lintas berbeda-beda sesuai dengan kondisi jalur lalu lintas. Karakter ini menyebabkan kemacetan yang berbeda dalam setiap segmen, sehingga untuk memodelkan persamaan matematika dengan karakteristik yang berbeda digunakan suatu persamaan sistem hybrid. Persamaan sistem hybrid merupakan gabungan persamaan matematika yang berbeda untuk merespon kasus dengan pendekatan pada variabel berbeda. Permasalahan jalur lalu lintas yang mengacu pada persamaan sistem hybrid yaitu persamaan matematika yang menggambarkan arus lalu lintas dan kelajuan kendaraan. Faktor yang dipertimbangkan dalam persamaan sistem hybrid bisa berbentuk kompleks sesuai dengan hubungan variabel dan tujuan dari gambaran suatu kasus. Pada penelitian ini, faktor yang sesuai pada kasus arus lalu lintas jalan tol menggunakan model makroskopik sehingga variabelnya dapat dibatasi.

\subsection{Model Arus Lalu Lintas Jalan Tol}

Penelitian ini membahas mengenai model makroskopik arus lalu lintas jalan tol dengan pendekatan non kontinum yang dinyatakan dalan persamaan sistem hybrid. Komponen yang digunakan dalam model arus lalu lintas ini adalah keseimbangan kendaraan yang bereaksi pada jarak dalam segmen. Pendekatan non kontinum berfungsi untuk memodelkan arus lalu lintas jalan tol dengan menggunakan beberapa "perwakilan" kendaraan di jalan tol (Tyagi et al, 2008).

Jalur lalu lintas yang dianalisis adalah jalur bebas hambatan atau jalan tol. Model makroskopik yang ditunjukkan bekerja cukup akurat dengan panjang segmen (Papageorgiou, 2004). Selain itu, setiap segmen diperbolehkan memiliki paling banyak satu persimpangan jalan kecil masuk dan satu persimpangan jalan kecil keluar yang terlihat pada gambar 1 . 


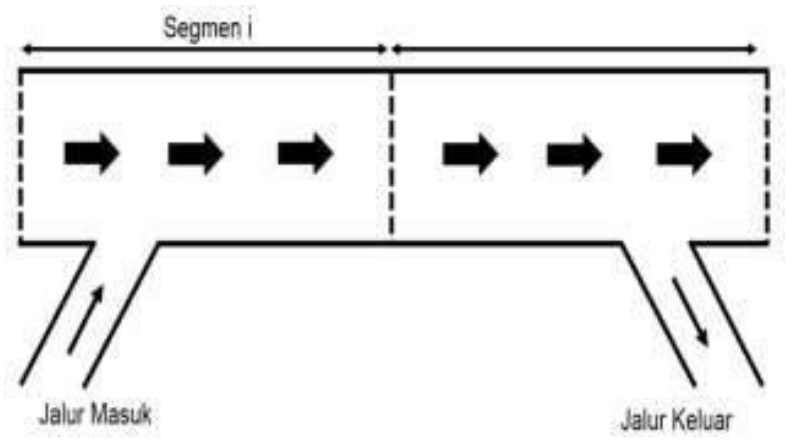

Gambar 9. Model Makroskopik Arus Lalu Lintas Jalan Tol

Pada persamaaan model makroskopik digunakan beberapa notasi, misalnya $\dot{N}$ sebagai tingkat laju perubahan dari jumlah kendaraan pada segmen terhadap waktu, kemudian banyaknya kendaraan pada segmen dinotasikan $N, N^{e n}$ menyatakan tingkat kendaraan yang masuk segmen jalan tol, $\dot{N}^{e x}$ merupakan tingkat laju perubahan dari jumlah kendaraan yang keluar segmen ke terhadap waktu (jika ada) dinotasikan, dan $\tilde{n}$ menotasikan tingkat kendaraan dengan jumlah bersih yang masuk ke segmen jalan tol dari jalur persimpangan.

Untuk variabel kelajuan kendaraan pada segmen dinotasikan $\dot{\bar{\Delta}}$ dan variabel rata-rata kelajuan relatif pada segmen dinotasikan $\bar{v}$. Kedua variabel tersebut dipengaruhi oleh tingkat rata-rata perubahan kelajuan relatif pada segmen yang dinotasikan $\dot{v}, L_{s}$ sebagai panjang segmen pada jalan tol, $\bar{L}_{c a r}$ menyatakan rata-rata panjang kendaraan yang melalui jalan tol, $h_{w}$ menotasikan waktu antara kendaraan (time headway), dan waktu konstan pengendara yang dinotasikan $\lambda$.

Keseimbangan kendaraan pada lalu lintas jalan tol dituliskan sebagai berikut.

$\dot{N}=N^{e n}-\dot{N}^{e x}+\tilde{n}$

Dalam memastikan kompatibilitas (penyesuaian arus jalan), tingkat kendaraan yang masuk segmen jalan tol sama dengan tingkat laju perubahan terhadap waktu dari jumlah kendaraan yang keluar segmen, sehingga dapat dikatakan:

$N^{e n}(k)=N^{e x}(k+1)$

dimana persamaan untuk tingkat laju perubahan terhadap waktu jumlah kendaraan yang keluar segmen merupakan rata-rata perubahan jarak yaitu,

$$
\dot{N}^{e x}=\frac{\dot{\bar{v}} N}{L_{s}}
$$

dimana $L_{s}$ adalah panjang segmen pada jalan tol.

Jarak kendaraan merupakan fungsi kelajuan relatif dan dihitung melalui persamaan (4) di bawah ini.

$$
\dot{\bar{\Delta}} \quad=-\frac{\left(\bar{L}_{c a r}+\bar{\Delta}\right)^{2}}{L_{s}} \dot{N}
$$


Persamaan tingkat perubahan kecepatan relatif dapat ditulis sebagai berikut.

$$
\dot{v}=\frac{1}{h_{w}}\left[\dot{\bar{\Delta}}+\lambda\left(\bar{\Delta}-h_{w} \bar{v}\right)\right]
$$

Selanjutnya, persamaan (1), (3), (4), dan (5) dapat dituliskan ke dalam matriks sebagai berikut.

$$
\left(\begin{array}{c}
\dot{N} \\
\dot{N}^{e x} \\
\dot{\bar{\Delta}} \\
\dot{v}
\end{array}\right)=\left(\begin{array}{c}
N^{e n}-\dot{N}^{e x}+\tilde{n} \\
\frac{\bar{v} N}{L_{s}} \\
-\frac{\left(\bar{L}_{c a r}+\bar{\Delta}\right)^{2}}{L_{s}} \dot{N} \\
\frac{1}{h_{w}}\left[\dot{\bar{\Delta}}+\lambda\left(\bar{\Delta}-h_{w} \bar{v}\right)\right]
\end{array}\right)
$$

\subsection{Metode Extended Kalman Filter (EKF)}

Algoritma Extended Kalman Filter ini digunakan dalam permasalahan tak linier untuk melakukan linearisasi pada rata-rata dan kovariansi tak linier. Misalkan diberikan model sistem dinamik stokastik tak linear:

$x_{k+1}=f\left(x_{k}, u_{k}\right)+w_{k}$

$z_{k}=h\left(x_{k}\right)+v_{k}$

dengan $x_{k} \in R^{n}$ adalah variabel keadaan (state), $z_{k} \in R^{m}$ adalah variabel pengukuran (measurement) dengan asumsi

$$
\begin{gathered}
x_{0} \sim N\left(\bar{x}_{0}, P_{x_{0}}\right) ; \\
w_{k} \sim(0, Q) ; \\
v_{k} \sim N(0, R)
\end{gathered}
$$

dalam hal ini variabel $w_{k} \sim N(0, Q)$ dan $v_{k} \sim N(0, R)$ diasumsikan tidak berkorelasi satu sama lain dan berdistribusi normal karena merupakan white noise.

Berikut Tabel 2.1 algoritma dari Extended Kalman Filter (EKF).

Tabel 1. Algoritma Extended Kalman Filter (EKF)

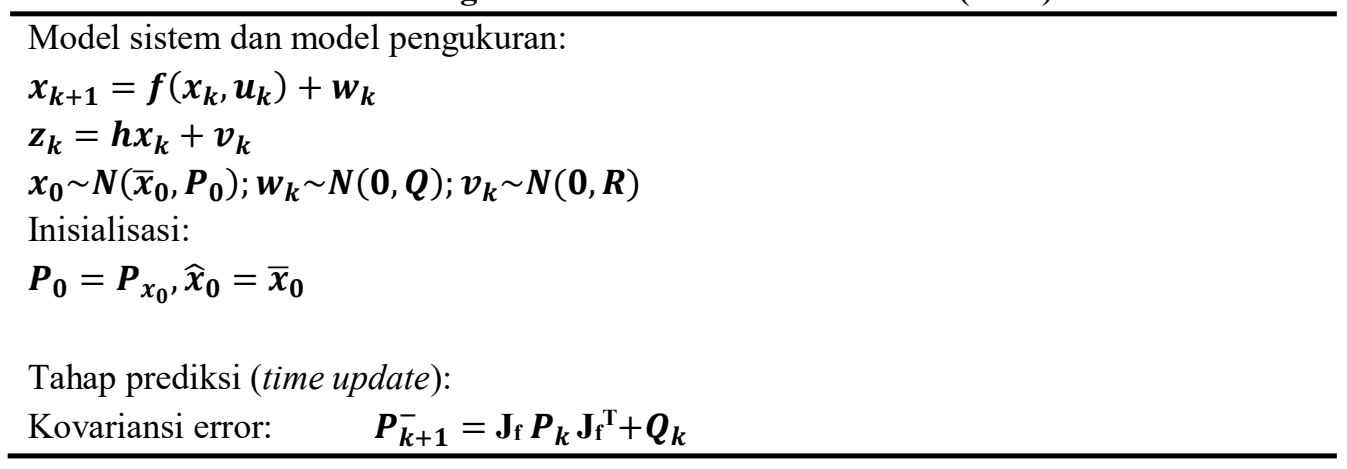




\begin{tabular}{lr}
\hline dengan & $\mathbf{J}_{\mathrm{f}}=\left[\frac{\partial f_{i}}{\partial x_{j}}\left(\widehat{\boldsymbol{x}}_{\boldsymbol{k}}, \boldsymbol{u}_{\boldsymbol{k}}\right)\right]$ \\
Estimasi: & $\widehat{\boldsymbol{x}}_{\boldsymbol{k}+\mathbf{1}}^{-}=\boldsymbol{f}\left(\widehat{\boldsymbol{x}}_{\boldsymbol{k}}, \boldsymbol{u}_{\boldsymbol{k}}\right)$
\end{tabular}

Tahap koreksi (measurement update):

$\begin{array}{ll}\text { Kalman Gain: } & \boldsymbol{K}_{\boldsymbol{k}+\mathbf{1}}=\boldsymbol{P}_{\boldsymbol{k}+\mathbf{1}}^{-} \mathbf{J}_{\mathrm{h}}^{\mathrm{T}}\left(\mathbf{J}_{\mathrm{h}} \boldsymbol{P}_{\boldsymbol{k}+\mathbf{1}}^{-} \mathbf{J}_{\mathbf{h}}^{\mathrm{T}}+\boldsymbol{R}_{\boldsymbol{k}+\mathbf{1}}\right)^{-\mathbf{1}} \\ \text { dengan } & \mathbf{J}_{\mathrm{h}}=\left[\frac{\partial \boldsymbol{h}_{\boldsymbol{i}}}{\partial \boldsymbol{x}_{\boldsymbol{j}}}\left(\widehat{\boldsymbol{x}}_{\boldsymbol{k}+\mathbf{1}}^{-}\right)\right] \\ \text {Kovariansi error: } & \boldsymbol{P}_{\boldsymbol{k}+\mathbf{1}}=\left[\boldsymbol{I}-\boldsymbol{K}_{\boldsymbol{k}+\mathbf{1}} \mathbf{J}_{\mathrm{h}}\right] \boldsymbol{P}_{\boldsymbol{k}+\mathbf{1}}^{-} \\ \text {Estimasi: } & \widehat{\boldsymbol{x}}_{\boldsymbol{k}+\mathbf{1}}=\widehat{\boldsymbol{x}}_{\boldsymbol{k}+\mathbf{1}}^{-}+\boldsymbol{K}_{\boldsymbol{k}+\mathbf{1}}\left(\mathbf{z}_{\boldsymbol{k}+\mathbf{1}}-\mathbf{J}_{\mathrm{h}} \widehat{\boldsymbol{x}}_{\boldsymbol{k}+\mathbf{1}}^{-}\right)\end{array}$

\subsection{Diskritisasi Model}

Dalam penelitian ini dilakukan pendiskritan model menggunakan metode beda hingga maju yaitu

$$
\frac{f_{i+1}-f_{i}}{\Delta x}=\frac{f\left(x_{1}+\Delta x\right)-f\left(x_{1}\right)}{\Delta x}
$$

(Burden dan Faires, 2011).

\subsection{Prosedur dan Pelaksanaan}

Langkah-langkah yang digunakan dalam mengestimasi kelajuan dan volume kendaraan pada arus lalu lintas jalan tol dengan menggunakan metode Extended Kalman Filter. Adapun metode penelitian yang digunakan adalah sebagai berikut.

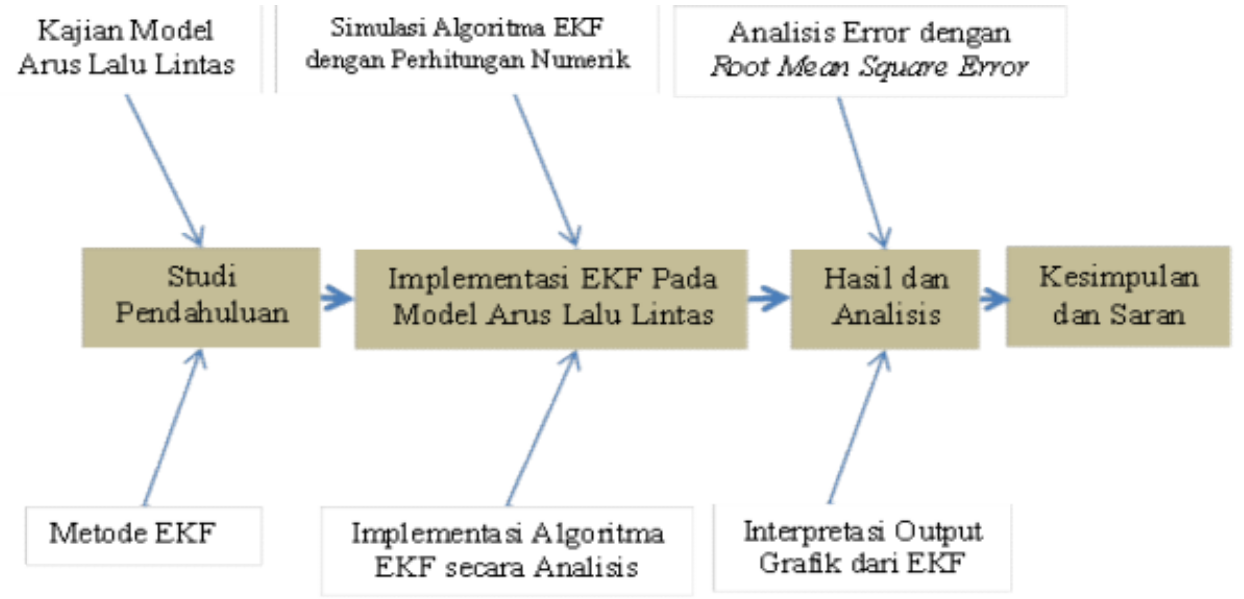

Gambar 10. Bagan Alur Penelitian

\section{Hasil dan Pembahasan}

Persamaan (6) pada model makroskopik dapat dituliskan kembali dalam matriks $4 \times 1$ sebagai berikut.

$$
\left(\begin{array}{c}
\dot{N} \\
\dot{N} \\
\dot{\bar{\Delta}}
\end{array}\right)=\left(\begin{array}{c}
N^{e n}-\frac{\bar{v} N}{L_{s}}+\tilde{n} \\
\frac{\bar{v} N}{L_{s}} \\
-\frac{\left(\bar{L}_{c a r}+\bar{\Delta}\right)^{2}}{\boldsymbol{I}}\left(N^{e n}-\frac{\bar{v} N}{\boldsymbol{I}}+\tilde{n}\right)
\end{array}\right.
$$


dan keluarannya adalah

$$
z=\left(\begin{array}{cccc}
1 & 0 & 0 & 0 \\
0 & 1 & 0 & 0 \\
0 & 0 & 1 & 0 \\
0 & 0 & 0 & 1
\end{array}\right)\left(\begin{array}{c}
\dot{N} \\
\dot{N} e x \\
\dot{\bar{\Delta}} \\
\dot{v}
\end{array}\right)
$$

Persamaan (11) merupakan model arus lalu lintas makroskopik pada jalan tol dengan waktu diskrit dan sistem model ini dapat disajikan dalam bentuk persamaan ruang keadaan (state space) yaitu

$$
\begin{gathered}
\left(\begin{array}{c}
N(k+1) \\
N^{e x}(k+1) \\
\bar{\Delta}(k+1) \\
v(k+1)
\end{array}\right)=\left(\begin{array}{c}
N(k)+\Delta t\left[N^{e n}(k)-\frac{\bar{v}(k) N(k)}{L_{s}}+\tilde{n}(k)\right] \\
N^{e x}(k)+\Delta t\left[\frac{\bar{v}(k) N(k)}{L_{s}}\right] \\
\bar{\Delta}(k)-\Delta t\left[-\frac{\left(\bar{L}_{c a r}+\bar{\Delta}(k)\right)^{2}}{L_{s}}\left(N^{e n}(k)-\frac{\bar{v}(k) N(k)}{L_{s}}+\tilde{n}(k)\right)\right] \\
v(k)+\Delta t \frac{1}{h_{w}}\left[\left(\frac{\left(\bar{L}_{c a r}+\bar{\Delta}(k)\right)^{2}}{L_{s}}\left(N^{e n}(k)-\frac{\bar{v} N(k)}{L_{s}}+\tilde{n}(k)\right)\right)+\lambda\left(\bar{\Delta}(k)-h_{w} \bar{v}(k)\right)\right]
\end{array}\right) \\
\tilde{n}(k)=N^{e n}(k)-N^{e x}(k)
\end{gathered}
$$

dan keluarannya adalah

$$
z=\left(\begin{array}{llll}
1 & 0 & 0 & 0 \\
0 & 1 & 0 & 0 \\
0 & 0 & 1 & 0 \\
0 & 0 & 0 & 1
\end{array}\right)\left(\begin{array}{c}
\dot{N} \\
\dot{N} e x \\
\dot{\bar{\Delta}} \\
\dot{v}
\end{array}\right)
$$

Langkah-langkah selanjutnya dalam metode EKF adalah sebagai berikut:

\section{1) Inisialisasi}

Inisialisasi awal dari masing-masing variabel keadaan untuk estimasi awal $\left(\hat{x}_{0}\right)$ dan kovarian $x,\left(P_{0}\right)$ yaitu

$$
\hat{x}_{0}=\bar{x}_{0}, P_{0}=P_{x_{0}}
$$

dengan $\bar{x}_{0}=\left[\begin{array}{llll}N(k) & N^{e x}(k) & \bar{\Delta}(k) & v(k)\end{array}\right]^{T}$ dan $P_{x_{0}}$ masing-masing merupakan matriks identitas yang berukuran $4 \times 4$.

\section{2) Tahap prediksi (time update)}

Pada tahap prediksi, dilakukan proses perhitungan estimasi dan kovarian error pada model sistem. Perhitungan dilakukan dengan model sistem yang sudah dilinearisasi melalui matriks Jacobian

$$
A=\mathbf{J}_{\mathbf{f}}=\left[f_{i, j}\right]=\left[\frac{\partial f_{i}}{\partial x_{j}}\left(\hat{x}_{k}, u_{k}\right)\right]
$$




$$
A=\left(\begin{array}{cccc}
\frac{\partial f_{1}}{\partial N(k)} & \frac{\partial f_{1}}{\partial N^{e x}(k)} & \frac{\partial f_{1}}{\partial \bar{\Delta}(k)} & \frac{\partial f_{1}}{\partial v(k)} \\
\frac{\partial f_{2}}{\partial N(k)} & \frac{\partial f_{2}}{\partial N^{e x}(k)} & \frac{\partial f_{2}}{\partial \bar{\Delta}(k)} & \frac{\partial f_{2}}{\partial v(k)} \\
\frac{\partial f_{3}}{\partial N(k)} & \frac{\partial f_{3}}{\partial N^{e x}(k)} & \frac{\partial f_{3}}{\partial \bar{\Delta}(k)} & \frac{\partial f_{3}}{\partial v(k)} \\
\frac{\partial f_{4}}{\partial N(k)} & \frac{\partial d f_{4}}{\partial N^{e x}(k)} & \frac{\partial f_{4}}{\partial \bar{\Delta}(k)} & \frac{\partial f_{4}}{\partial v(k)}
\end{array}\right)
$$

Berikutnya, dilakukan perhitungan untuk kovarian dan estimasi dengan algoritma EKF yang tertera pada Tabel 2.1 yaitu

Kovariansi error: $\quad \boldsymbol{P}_{\boldsymbol{k}+\mathbf{1}}^{-}=\mathbf{J}_{\mathrm{f}} \boldsymbol{P}_{\boldsymbol{k}} \mathbf{J}_{\mathrm{f}}^{\mathrm{T}}+\boldsymbol{Q}_{\boldsymbol{k}}$

Estimasi: $\quad \widehat{\boldsymbol{x}}_{\boldsymbol{k}+\mathbf{1}}^{-}=\boldsymbol{f}\left(\widehat{\boldsymbol{x}}_{\boldsymbol{k}}, \boldsymbol{u}_{\boldsymbol{k}}\right)$

Dengan kovarian dari noise sistem $Q_{k}$ merupakan matriks diagonal/identitas dengan ukuran $4 \times 4$. Perhitungan ini dilakukan dalam sistem komputer.

\section{3) Tahap koreksi (measurement update)}

Pada tahap koreksi, perhitungan yang dilakukan terlebih dahulu yaitu menentukan nilai Kalman Gain dan selanjutnya kovarian error dan estimasi melalui model pengukuran yaitu

Kalman Gain: $\quad \boldsymbol{K}_{\boldsymbol{k}+\mathbf{1}}=\boldsymbol{P}_{\boldsymbol{k}+\mathbf{1}}^{-} \mathbf{J}_{\mathrm{h}}^{\mathrm{T}}\left(\mathbf{J}_{\mathrm{h}} \boldsymbol{P}_{\boldsymbol{k}+\mathbf{1}}^{-} \mathbf{J}_{\mathrm{h}}{ }^{\mathrm{T}}+\boldsymbol{R}_{\boldsymbol{k}+\mathbf{1}}\right)^{-\mathbf{1}}$

Kovariansi error: $\quad \boldsymbol{P}_{\boldsymbol{k}+\mathbf{1}}=\left[\boldsymbol{I}-\boldsymbol{K}_{\boldsymbol{k}+\mathbf{1}} \mathbf{J}_{\mathrm{h}}\right] \boldsymbol{P}_{\boldsymbol{k}+\mathbf{1}}^{-}$

Estimasi: $\quad \widehat{x}_{k+1}=\widehat{x}_{k+1}^{-}+K_{k+1}\left(z_{k+1}-\mathbf{J}_{\mathrm{h}} \widehat{x}_{k+1}^{-}\right)$

dengan $\quad \boldsymbol{H}=\mathbf{J}_{\mathrm{h}}=\left[\frac{\partial h_{i}}{\partial x_{j}}\left(\widehat{\boldsymbol{x}}_{\boldsymbol{k}+1}^{-}\right)\right]$

dimana $z_{k}$ merupakan data pengukuran yang bersifat random. Kovarian dari noise pengukuran $R_{k}$ merupakan matriks diagonal dengan ukuran $4 \times 4$ dan untuk matriks $\mathrm{H}$ diasumsikan linier, sehingga $\mathrm{H}$ merupakan matriks diagonal ukuran $4 \times 4$ dengan perkalian dari rentang waktu yaitu $d t$ sebagai berikut:

$$
H=\left[\begin{array}{cccc}
\Delta t & 0 & 0 & 0 \\
0 & \Delta t & 0 & 0 \\
0 & 0 & \Delta t & 0 \\
0 & 0 & 0 & \Delta t
\end{array}\right]
$$

4) Setelah tahap koreksi (measurement update), kembali lagi pada tahap prediksi yaitu langkah ke3 untuk iterasi pada waktu $k+1$ dan selanjutnya sampai waktu yang diinginkan yaitu $m$.

Dalam simulasi ini, nilai awal variabel dan parameter yang digunakan adalah sebagai berikut.

\section{Tabel 2. Nilai Awal dari Variabel dan Parameter}

Notasi
$N(k)$
$N^{e x}(k)$
$\bar{\Delta}(k)$
$v(k)$
$\Delta t$

Nama

jumlah kendaraan pada segmen

jumlah kendaraan keluar segmen

jarak kendaraan

kelajuan kendaraan

rentang waktu
Nilai awal dengan waktu $t=0$

16

6

7 meter

123,5 meter/menit

30/3600 menit 


$\begin{array}{ccc}\text { Notasi } & \text { Nama } & \text { Nilai awal dengan waktu } \mathrm{t}=0 \\ \tilde{n} & \text { jumlah kendaraan tersisa pada segmen } & 4 \\ N^{\text {en }} & \text { jumlah kendaraan masuk segmen } & 6 \\ L_{c a r} & \text { panjang kendaraan } & 5 \text { meter } \\ L_{s} & \text { panjang segmen } & 200 \text { meter } \\ h_{w} & \text { waktu antar kendaraan } & 0,25 \\ \lambda & \text { waktu Konstan } & 1,2 \times 10^{-7} \\ Q_{k} & \text { Error model } & 3 \\ R_{k} & \text { Error pengukuran } & 3\end{array}$

Pada simulasi ini dilakukan plot grafik dengan rata-rata running sebanyak kelipatan 60 kali dan jumlah iterasi yang dijalankan adalah 50. Berikut adalah plot grafik EKF dari running sebanyak 100000 kali.
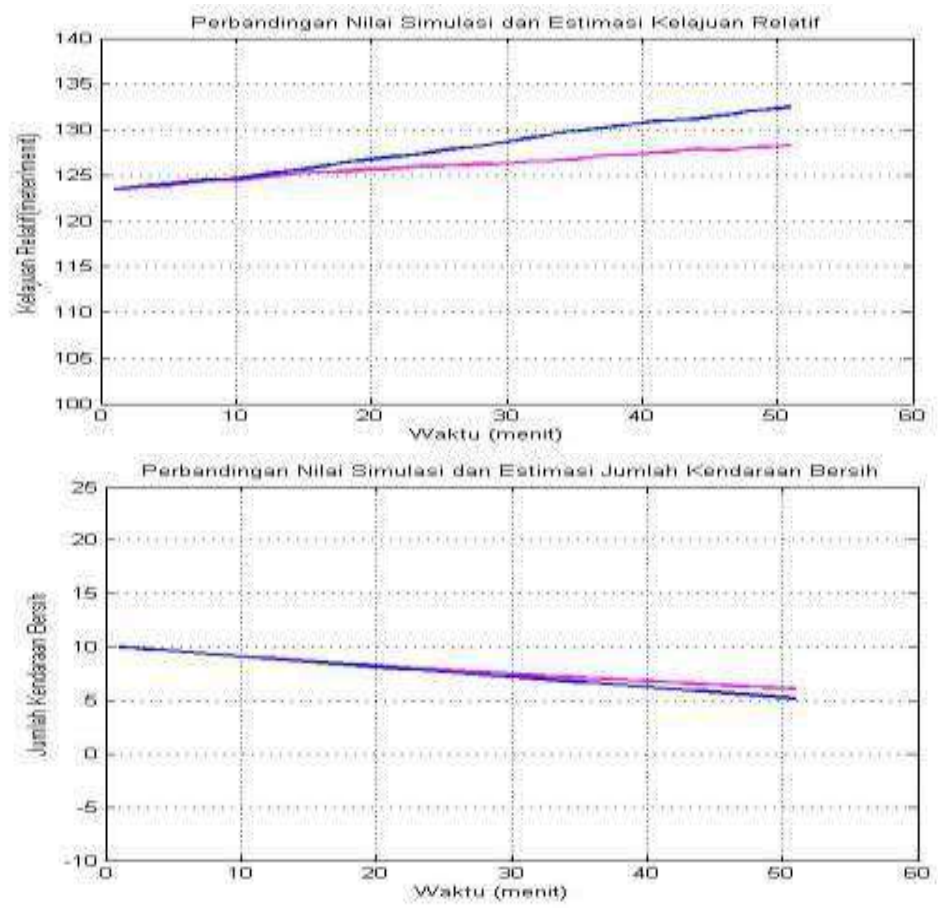

\section{Nilai Simulasi
EKF \\ Gambar 11. Grafik Nilai Simulasi dan EKF dari Kelajuan Relatif dan Jumlah Kendaraan Bersih Kendaraan}

Pada metode Extended Kalman Filter yang digunakan, untuk memberikan estimasi dari analisa antara volume kendaraan dengan kelajuan relatif pada arus lalu lintas jalan tol, gambar 4.5 adalah hasil yang dapat memberikan gambaran untuk estimasi tersebut dengan melihat kesalahan terkecil pada perhitungan numerik.

Pada gambar 4.5, terlihat bahwa rata-rata kelajuan relatif kendaraan pada segmen dengan panjang 200 meter meningkat ketika jumlah kendaraan bersih pada segmen berkurang. Hal itu disebabkan jarak antar 
kendaraan saling berjauhan dengan kendaraan di depannya, demikian juga sebaliknya ketika rata-rata jumlah kendaraan meningkat maka jarak antar kendaraan semakin dekat dan kelajuan relatif kendaraan menjadi menurun.

\section{Kesimpulan}

Berdasarkan analisis dan pembahasan yang telah dilakukan, dapat disimpulkan beberapa hal sebagai berikut :

1. Metode Extended Kalman Filter bisa digunakan untuk mengestimasi dan menganalisis antara kelajuan dan volume kendaraan pada model arus lalu lintas jalan tol, sehingga dapat mengetahui hubungan yang terjadi antara kepadatan dengan rata-rata kelajuan relatif.

2. Analisis antara kelajuan dan volume kendaraan pada penelitian ini menyatakan bahwa prediksi ratarata kelajuan relatif kendaraan pada segmen terjadi penurunan ketika jumlah kendaraan bersih pada segmen meningkat. Hal itu disebabkan oleh jarak antar kendaraan yang semakin dekat dengan kendaraan di depannya, demikian juga sebaliknya ketika rata-rata jumlah kendaraan berkurang, maka jarak antar kendaraan semakin jauh dan kelajuan relatif kendaraan menjadi tinggi.

3. Hasil estimasi Extended Kalman Filter ini akan jauh lebih baik dengan memperhatikan variabel kelajuan dan jarak antar kendaraan, karena kedua variabel ini mempengaruhi nilai simulasi dari EKF. Hal ini bertujuan untuk mendapatkan nilai simulasi yang mendekati nilai real dari hasil perulangan pada perhitungan numerik, sehingga didapatkan perkiraan terbaik untuk keterkaitan antara kelajuan relatif dengan volume kendaraan bersih dengan nilai RMS terkecil.

4. Kelajuan merupakan faktor penting dalam model arus lalu lintas jalan tol karena bisa memberikan informasi secara langsung pada parameter yang lainnya untuk menentukan nilai estimasi masingmasing parameter.

\section{Saran}

Pada Tugas Akhir ini, model arus lalu lintas makroskopik jalan tol merupakan sistem model tak linier. Untuk mengetahui keefektifan metode estimasi yang digunakan, bisa diterapkan beberapa metode estimasi yang lain, misalnya Ensamble Kalman Filter. Selain itu, perlu juga diperhatikan beberapa variabel tambahan model arus lalu lintas ini, seperti lebar jalan, luas jalan, dan luas kendaran, agar diperoleh model yang lebih akurat.

\section{References}

Burden, R.L., dan Faires, J. D. 2011. Numerical Analysis, Ninth Edition. Youngstown State University.

Kerner, B.S. 2009. Introduction to Modern Traffic Flow Theory and Control. Springer-Verlag Berlin Heidelberg. Berlin. Germany.

Lewis, FL.1986. Optimal Estimation with an Introduction to Stochastic Control Theory. $2^{\text {nd }}$ ed. School of Electrical Engineering, Georgia Institute of Tchnology: Atlanta, Georgia.

Luknanto, D. 2003. Model Matematika; Bahan kuliah Hidraulika Komputaasi. Jurusan Teknik Sipil Universitas Gajah Mada.

Mathew, T.V. 2014. Transportation System Engineering. IIT Bombay. India.

Morrel, D. 1997. Extended Kalman Filter Lecture Notes. EEE581-Spring1997.

Nagatani, T. 2015. Traffic Jam at Adjustable Tollgates Controlled by Line Length. Prog. Physica A 442(2016) 131-136. Japan.

Papageorgiou, M., dan Yibing, W. 2005. Real-Time Freeway Traffic State Estimation Based on Extended Kalman Filter: A General Approach. Transportation Research Part B 39 (2005) 141-167.Greece.

Darbha, S., dan Rajagopal, K. R. 2002. Limit of a collection of dynamical systems: An application to modeling the flow of traffic, Mathematical Models and Methods in Applied Sciences 12 (10) (2002) 1381-1399. 
Terejanu, G.A. 2008. Extended Kalman Filter Tutorial. Web-tutorial, Department of Computer Science and Engineering, University at Buffalo. Buffalo, New York.

Tyagi, V., S. Darbha, dan Rajagopal, K. R. 2008. Adynamical Systems Approach Based on Averaging to Model the Macroscopic flow of freeway traffic. Non linear Analysis: Hybrid Systems 2(2008)590-612.

Welch, G., dan Bishop, G. 2001. An Introduction to the Kalman Filter. Course 8. ACM,Inc, University of North Carolina: Chapel Hill.

Yusnita, Y. 2016. Simulasi Arus Lalu Lintas dengan Menggunakan Kecepatan Model Kerner Konhauser. Jurusan Matematika. Tesis. Universitas Riau Kepulauan Batam.

Zhang, L, dan X Mao, X. 2015. Vehicle Density Estimation of Freeway Traffic with Unknown Boundary DemandSupply: An IMM Approach. University of Strathclyde, Glasgow. 